\title{
A Fregoli családnévből származó szavak a magyar nyelvben
}

1. Közismert, hogy a 20. század elején sikeres „átváltozóművészi” pályát befutó olasz Leopoldo Fregoli családneve különböző alakokban és jelentésekben több nyelvbe is átkerült, mind tulajdonnévi, mind köznévi funkcióban. A magyarba bekerült esetek (olykor bővebb magyarázattal) több szótárunkban is megtalálhatók, sőt: született a név magyar vonatkozásairól néhány részletesebb elemzés is (olasz nyelven: BENEDEK 1978: 150; FÁBIÁN 2001: 61-65, 2015: 118-119, 2019). Ebben a tanulmányban a családnév magyar továbbéléséről adunk részletes áttekintést, és igyekszünk megállapításainkat a korabeli sajtóból nyert adatokkal is alátámasztani.

E név esetében az elemzés lehetőségei és nehézségei különösen szoros öszszefüggésben állnak a Fregoli névnek a befogadó magyar nyelvben meglévő funkcionális és formai gazdagságával. Vizsgálatunkban először a transzonímia, másodjára pedig a deonímia kategóriájába tartozó eseteket vesszük számba. (Ilyen módszer alkalmazására előzményként és mintaként hivatkozható pl. CAFFARELLI 2013, 2017; a használt terminusokhoz 1. BÖLCSKEI-FARKAS-SLÍZ szerk. 2017.)

Először tehát azokkal az esetekkel foglalkozunk, amelyekben a müvész családneve egy másik tulajdonnévi kategóriába vándorolt át, illetve jelzőként olyan szintagma része lett, amelyben megőrizte tulajdonnévi funkcióját (transzonímia, 3. pont). A második nagyobb részben a köznevesült alakokat vesszük sorra (melyek között szintén lehetnek képzett formák is), és itt is felsoroljuk a szókapcsolatokban megjelenő eseteket is, amelyekben a rendszerint metaforikus átvitel miatt a családnév már elvesztette tulajdonnévi funkcióját (deonímia, 4. pont).

Itt jegyezzük meg, hogy az internetes anyag- és adattgyüjtés a 2018 szeptembere 2019 júniusa közötti periódusban zajlott. Helykímélés céljából az interneten elért és dátummal azonosított sajtóforrások URL-címét nem adjuk meg.

2. Leopoldo Fregoli (Róma, 1867. július 2. - Viareggio, 1936. november 26.) a 20. sz. első évtizedeiben volt világhírủ színész és ún. ,átváltozóművész” (angol megnevezése szerint: quick change artist). Briliáns karrierje ${ }^{1}$ katonai szolgálata alatt kezdődött, amikor Maszavában (Eritrea) a tiszti klubban egymaga adott elő többszereplös jeleneteket. Rómába visszatérve kezdte azután tökéletesíteni azt a fajta előadómüvészi ágat, ami világhírüvé tette: előre megírt (és zenével kísért)

${ }^{1}$ Életéről a Wikipedia hat nyelven ír, az olasz verzió (https://it.wikipedia.org/wiki/Leopoldo Fregoli) több mint tíz, Fregoli életét leíró könyvről tud; ezek közül a Fregoli raccontato da Fregoli címü (Rizzoli, Milano-Roma, 1936) önéletrajzi írást 2007-ben újra kiadták (Florence Art, Firenze). - Itt jegyezzük meg, hogy Szilágyi György író és humorista Komédia nagyban és kicsinyben címü, a magyar cirkusz és varieté történetét tréfás színezettel is ecsetelő könyvében a Fregolira vonatkozó részeknél - talán szándékosan - olyan téves megjegyzések is szerepelnek, mint például a mủvész szicíliai származása vagy a kertész foglalkozás megjelölése (Lapkiadó Vállalat, Budapest, 1985: 16-22).

Magyar Nyelv 115. 2019: 283-297. DOI: 10.18349/MagyarNyelv.2019.3.283 
kis történetekben minden szerepet ő játszott, időnként eltünve a színpadi függöny mögött, ahol segítői gyorsan átöltöztették (akár nőnek is). Karrierje során számos hosszabb-rövidebb turnén járt a széles világban. Louis Lumière-rel (1897-ben Lyonban) történt találkozása után ötlötte ki a Fregoligraph intézményét: ezek a jeleneteinek a megfilmesített változatai voltak, melyeket rendszerint programja végén vetítettek le (és nyilván reklám céljára szolgáltak). ${ }^{2}$ Karrierje csúcsán (egy impresszárióváltás miatt) anyagi csődbe került, ezért tovább folytatta fellépéseit, egészen 1925-ig, amikor is végleg visszavonul viareggiói villájába. ${ }^{3}$

Ahogyan azt a korabeli újságokból (és egyéb forrásokból ${ }^{4}$ ) tudjuk, az immár világhírủ előadómủvész a magyar fővárosban is járt, ${ }^{5}$ mégpedig az 1900 . december 1. - 1901. január 31. közötti időszakban, és a Somossy Orfeumban lépett fel. Programján nyolc különböző darab ${ }^{6}$ szerepelt (zárójelben az olasz cím és a szerepek száma áll): Relampago a gyorspincér / villámpincér (Relampago ${ }^{7}$ o Il cameriere lampo, 7 szerep); A méh (L’Ape, 8 szerep); A Becsületesség (L'Onestà, 9 szerep); 9 óra 23 perc (?, 9 szerep); Az Eldorádó (Eldorado); Chameleon (Il Camaleonte, 5 szerep); A sorentoi [sic!] leánynevelö intézetben (Le educande di Sorrento, 2 szerep); Mimi (Mimì, 6 szerep).

${ }^{2}$ Ez egy 4 x 3 méteres, színes lámpákkal keretezett vetítőernyő volt, amelynek Fregoli adta a Fregoligraph nevet. (Dizionario Biografico degli Italiani. Treccani. 50. kötet. 1998: 37, http://www. treccani.it/enciclopedia/leopoldo-fregoli_(Dizionario-Biografico). L. még ehhez: CoLAGRECO, LUIGI, Verso la multimedialità? Gli spettacoli di Leopoldo Fregoli fra teatro e cinema, http://www. trax.it/olivieropdp/ateatro2002/fregoli.htm.)

${ }^{3}$ Haláláról Fregoli halálában is becsapta a közönséget címmel adott hírt a Prágai Magyar Hírlap (1936. dec. 2.). Sírja ma a római Verano temetőben van. - A Kis Újság (1936. nov. 29.) összetéveszti Girolamo Tatullival (hibásan írva a vezetéknevét: Tattuli), aki Frizzo Fregoli néven a Fregoli-utánzók népes sorába tartozott (1. még később).

${ }^{4}$ Ilyen például Jon Letamendi és Jean-Claude Seguin Vergara írása a turnék időpontjának aprólékos felsorolásával (https://www.grimh.org/index.php?option=com_content\&view=article\&layout=e dit\&id=1159\&lang=fr). Mint látni fogjuk, Fregoli budapesti tartózkodásának dátuma döntő fontosságú bizonyos, a magyar jelentések motivációjának feltárásával kapcsolatos információk helyretételében.

${ }^{5}$ Ezt a rövid budapesti látogatást csak néhány forrás említi meg.

${ }^{6}$ Forrásaink a Pesti Hírlap és a Budapesti Hírlap voltak: ezekben (és más) a napilapokban Fregoli budapesti tartózkodása alatt naponta voltak reklámok.

${ }^{7}$ A relámpago szó jelentése spanyolul: 'villám', és talán a spanyol nyelvterület (ahol Fregoli gyakran járt) nézőinek a kedvéért ez a szereplő neve. A villámpincér szó tükörfordítás - a magyar közönségnek. 


\section{1. ábra}

A méh címü Fregoli-előadás reklámja (Magyar Nemzet 1900. dec. 12.)

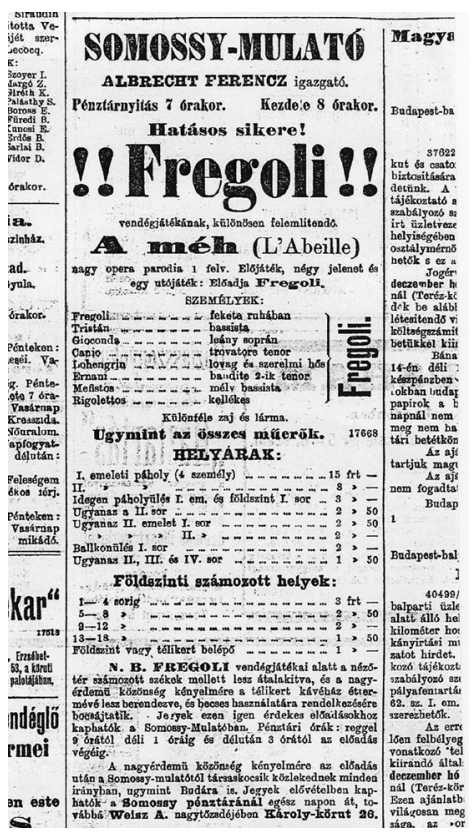

Az egyik előadás (1901. jan. 10.) bevételeit jótékonysági célokra ajánlották fel. ${ }^{8}$ A budapesti előadások végén is müködött a Fregoligraph. A fövárosban a müvész összesen $\mathrm{kb}$. hetvenszer lépett fel, ugyanis voltak délutáni és esti elöadások is. Fregoli 1901 januárjának végén hagyta el Budapestet, és a bécsi Carl Theaterben folytatta sikersorozatát. A Somossy Orfeum 1901. áprilisi programjában viszont már megjelentek a Fregolit felidéző, őt utánzó müsorok (pl. a Fregoliinduló, illetve Baumann Károly Fregoli-paródiája ${ }^{9}$ ): úgy tünik, hogy a mulató vezetői így kívánták meghosszabbítani az olasz múvész közönségvonzó sikerességét. A Fregoli-utánzók száma még szaporodott: 1903-ban például Gyöngyi Izsó (1860-1923) magyar színész lépett fel a karneváli időszakban Nagykanizsán a nagy táncteremben egy A magyar Fregoli című számmal, ${ }^{10}$ de még hosszú évtizedeken át fel-felbukkantak olasz ${ }^{11}$ és magyar ${ }^{12}$ imitátorok.

\footnotetext{
${ }^{8}$ A felajánlás 3000 korona volt (Pesti Napló 1901. jan. 11.), bevételei után azonban Fregolinak 400 korona adót is kellett fizetnie (Pesti Napló 1901. jan. 15.).

${ }^{9}$ L. Wikipedia (https://hu.wikipedia.org/wiki/Baumann_K\%C3\%A1roly).

${ }^{10}$ A magyar cím: A magyar Fregoli (Zalamegye 1903. febr. 15: 5).

${ }^{11}$ Magyarországon is járt Frizzo-Fregoli, aki - a helyi újságokban megjelent közlemények szerint - 1904-ben és 1906-ban turnén volt Debrecenben, Kecskeméten, Pápán, Nagykanizsán és Pécsett is. A Szamos c. újság 1904. febr. 28-i számában hosszabb cikk olvasható müsoráról. - 1910ben egy bizonyos Jassy Fregoli neve bukkan fel a sajtóban szegedi (Délmagyarország 1910. júl. 6: 10) és szatmári (Szamos 1910. júl. 31: 5) fellépései kapcsán.

${ }^{12}$ L. pl. a Budai Napló c. újságban (1919. febr. 23: 3.) megjelent hírt.
} 


\section{Transzonímia}

3.1. Tulajdonnévből tulajdonnév. Fregoli népszerüségének egyik első nyelvi vonatkozású következménye az volt, hogy családnevét néhányan álnévnek választották. 1901-ben jelent meg például az a 27 oldalas, a hasbeszélés müvészetéröl szóló, Gerő I. Imre által kiadott könyvecske, melynek szerzője egy állítólagos Fregoly ${ }^{13}$ (tehát a „magyaros” -y végződéssel). Két évtizeddel később a Színházi Világ címủ lap humoros rovatát jegyezte a szerző Fregoli álnévvel. ${ }^{14}$ Úgy tűnik, még ma is eszébe juthat valakinek e név álnévként való használata: a Facebookon találtunk ugyanis egy bizonyos Madame Fregoli-t. ${ }^{15}$ - Itt említhetjük még meg, hogy Molière Le Médecin volant (1645) címü, tartalmilag szerepcserén, megtévesztésen alapuló egyfelvonásosát Réz Ádám a 20. sz. közepén Doktor Fregoli címmel magyarította: ${ }^{16}$ (a darab olykor Fregoli doktor névsorrendü címmel is feltünik magyar forrásokban ${ }^{17}$ ). Egy korábbi, 1884-ben megjelent másik magyar fordítás (Toldy László munkája) még - a „szó szerinti” - A repülő orvos címet viselte. ${ }^{18}$

A Fregoli név - ennek egyik lehetséges nöi változatával együtt - már egy a 20. század elején játszott színházi darab címében is felbukkant: az Egy borbély család kalandjai vagy Fregoli és Fregolina címü, négy felvonásos ,énekes bohózat” ősbemutatója 1903. szept. 3-án volt a Városligeti Színkörben. ${ }^{19}$ Szerzője Déry Miklós ${ }^{20}$ (társszerző: Koller Béla), a zenét Daniello Cipoleoni (sic!, ALPÁR 1991: 102) szerezte.

A Fregoli név nőt jelölő variánsai (Fregolina, Fregolia) tehát már a müvész aktív pályafutása alatt megjelentek, és személynévként vagy más típusú tulajdonnevekként is használatosak lettek. A „női Fregolik” sorában szerepelt a híres Fedák Sári már 1901-ben, Fregolina néven. ${ }^{21} 1906$ tavaszán a magyar újságok reklámozták az alig 8 éves olasz Tina Parri turnéját, aki szintén Fregolina álnéven lett híres. ${ }^{22}$ A (Miss) Fregolia müvésznév 1911-ben és 1918-ban ${ }^{23}$ is felbukkant a magyar újságokban, sőt (talán már egy másik személyre vonatkoztatva?) még 1933-ban is, ezúttal magyar utónévvel párosítva (Fregolia Ica ${ }^{24}$ ). 1915-ből találtunk adatokat (elsősorban szegedi és pápai napilapokban) a Miss Sheba (the Lady)

${ }^{13}$ A hasbeszélés müvészete. Utasítások a hasbeszélés mesterségének gyors elsajátítására és állathangok utánzására (Gerő I. Imre, Budapest, 1901).

${ }^{14}$ Színházi Világ 1921. máj. 7.

${ }^{15}$ Alias Kurucz Adrienn (https://en-gb.facebook.com/madamefregoli, 2019. febr. 25-én megtekintve).

${ }^{16}$ Magyar Helikon Kiadó, Budapest, 1965: 21-36.

${ }^{17}$ Mégpedig elsősorban egy 2017-es debreceni előadás kapcsán, egyúttal - tévesen - Réz Pálnak tulajdonítva a magyar fordítást. (1. pl. http://deszinhaz.hu/fregoli-a-padon).

${ }^{18}$ Athenaeum, Budapest, 1884. (1. Gragger Róbert, Molière első nyomai a magyar irodalomban. Irodalomtörténet 19. 1909: 324).

${ }^{19}$ A darab tartalma le van írva a Magyar Színpad c. lapban (1903. szept. 27: 4).

${ }^{20}$ A név Déri változatban is előfordult.

${ }^{21}$ Budapest Hírlap 1901. márc. 10.

${ }^{22}$ Úgy tünik (1. Magyar Színpad 1906. máj. 21: 3), hogy magyarországi fellépésére végül nem került sor

${ }^{23}$ Fellépett például a Fővárosi Orfeumban (Fővárosi Hírlap 1918. aug. 28., szept. 11.) és Debrecenben a Vígszínházban (1918. dec. 6., 7.).

${ }^{24}$ Valószínűleg egy magyar mủvésznő álneve lehetett. (Délmagyarország 1933. okt. 5: 7). 
Fregoli müvésznévre; 1925-ből valón ${ }^{25}$ a Hella ${ }^{26}$ Fregolia müvésznév (viselőjéről a „hasbeszélés müvészeként” szólnak).

A női Fregolia és Fregolina névváltozatok felbukkantak a magyarban további tulajdonnévi funkciókban is, mégpedig elsősorban mint márkanevek. A Fregolia nevet adták például a harmincas években egy akkor egy budapesti társaság által gyártott, 80 x $60 \mathrm{~cm}$ méretü, összecsukható lemezkádnak. ${ }^{27} \mathrm{Az}$ egyik online piactéri oldalon fellelt, ${ }^{28}$ a kádról készült fényképen jól látszik a márkanév (Fregolia) és a gyártó neve, címe is. Ezt azért fontos megjegyezni, mert korabeli sajtóorgánumokban e tárgy jelölésére más név $\left(\right.$ Fregolina $\left.^{29}\right)$ is feltünt. ${ }^{30}$

\section{2. ábra}

Fregolia összecsukható fürdőkád

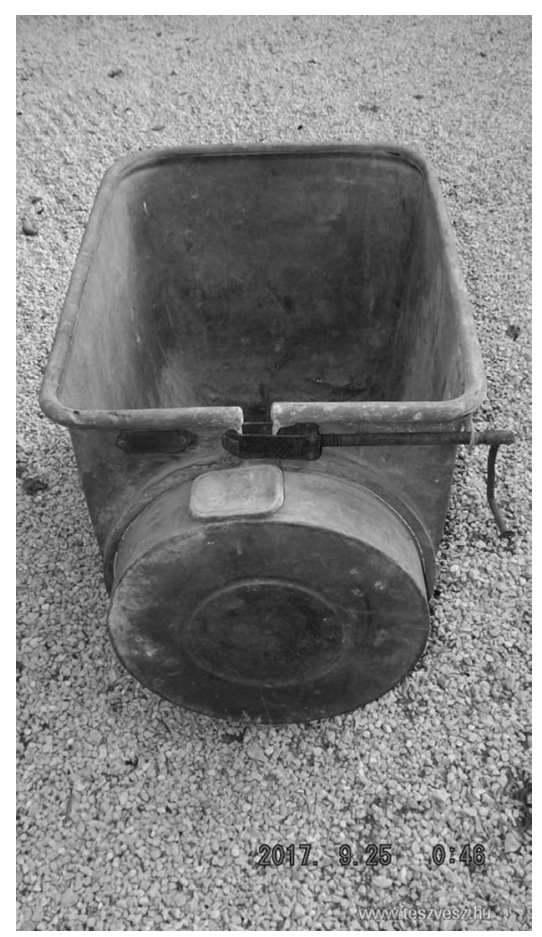

${ }^{25}$ Nyírvidék 1925. márc. 4: 6.

${ }^{26}$ Német vagy északi név.

${ }^{27}$ Az Est c. újságban közreadott (1930. jún. 6: 9) reklámot rajzzal is illusztrálták (egy hölgy fürdik a fürdőkádban).

${ }^{28}$ A feliraton ez olvasható: „FREGOLIA összecsukható fürdőkád MAKART Budapest VI. Lovag út 19 Magyar Királyi Szabadalom” (a fürdőkádat 2019 márciusában kínálták 12000 Ft-ért; https://www.vatera.hu/antik-fregolia-osszecsukhato-furdokad-ritkasag-2651372828.html).

${ }^{29}$ Itt a Lovag utca 21. van címként megadva (Budapesti Hírlap 1930. okt. 4: 13).

${ }^{30}$ Címként itt is a Lovag utca 19. van megadva (Eger 1930. jún. 22: 4), ami megegyezik a korabeli budapesti telefonkönyv 1939-es elöfizetőinek névsorában fellelhető címmel. 


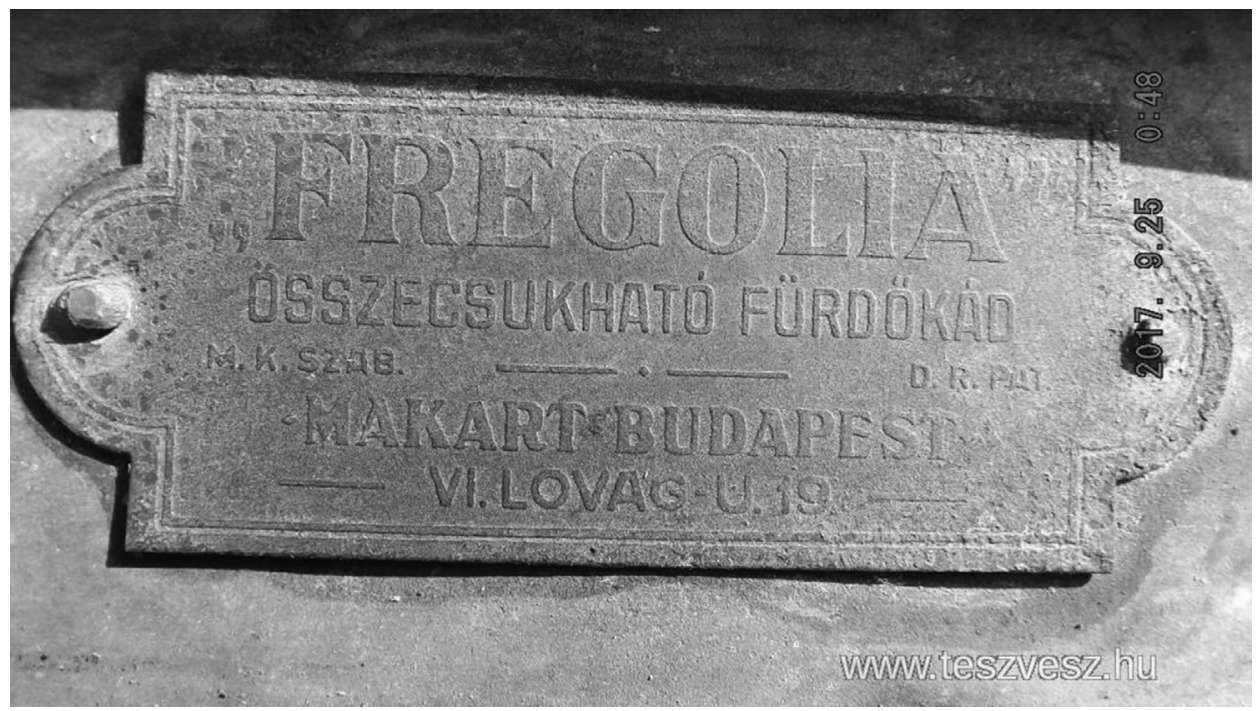

A Fregolina márkanévre találtunk (szintén rövid életü) adatot a második világháború utáni időszakból is: egy színét változtató fülklipszet is így neveztek. ${ }^{31}$

Szintén transzonímiáról van szó a Fregoli lónév esetében. Már a 20. sz. elején (1903) így nevezte el egyik lovát Liptay Béla. ${ }^{32} \mathrm{~A}$ húszas-harmincas években $\mathrm{Bu}-$ dapesten versenyző, szintén Fregoli nevü ló már valószínúleg egy másik paripa. ${ }^{33}$

A tulajdonnévi használatok között megemlítjük, hogy címekben is felbukkan a Fregoli tulajdonnév. Az időben az első ilyen jellegü használatot 1901-ből leltük fel, amikor is Fregoli-induló volt a magyar megfelelöje az amerikai J. P. Sousa Stars and stripes (forever) című indulójának ${ }^{34}$ (a magyar cím motivációját egyelöre nem tudtuk megfejteni). Később (1917-1919 között) használták a nevet a Fidibusz címü szatírikus-irodalmi újság „fedőcímeként” is. ${ }^{35}$ A kilencvenes években azután a TOP TV egyik müsorának volt a címe Fregoli-Klipek. ${ }^{36}$ 2005-ben pedig felbukkant a Lakáskultúra címủ magazin időszakos mellékletének címeként is.

3.2. Tulajdonnevet tartalmazó szintagmák. Áttérünk a Fregoli családnevet tartalmazó olyan szintagmák tárgyalására, amelyben az olasz müvész családneve

${ }^{31}$ Az eladó: Somló József, Budapest, Andrássy út 27. (Haladás 1948. szept. 2: 2).

${ }^{32}$ A ló elnevezéséről a Vadász és verseny-lap számolt be (1903. szept. 11: 549, 1906. aug. 17: 485).

${ }^{33} 8$ órai újság (1932. ápr. 9.) és további hírek az MTI-től.

${ }^{34} \mathrm{Ez}$ az adat zenei antikváriumok honlapjairól, illetve napilapokból került látóterünkbe (pl. https://library.hungaricana.hu/hu/view/Zalamegye_1901_1/?pg=105\&layout=s). Használatos volt a Fregoli-Marsch cím is. - 1908. máj. 12-i adat a debreceni Városi Színház plakátjáról: a Narancsvirág címü darab betétdalaként a Fregoli-indulót „,üttyöli Fisch Lajosné urnő”.

${ }^{35}$ Ebben a két évben a Fidibusz (melyet 1917-1927 között adtak ki) ezen a néven nem volt árusítható nyilvános helyeken (csak az előfizetőknek maradt meg az eredeti címen a lap), és helyettesítő névnek a Fregoli címet választották. (L ehhez: LAKATOS 1979: 153; NAGY é. n.; SEREG 2012: 555.)

${ }^{36}$ A TOP TV 1995-1996 között müködött, zenei müsorokat sugárzott. (https://hu.wikipedia. org/wiki/Top_TV). 
megőrizte tulajdonnévi szerepét. Ennek a típusnak az esetében felmerül a nagybetüs vagy kisbetüs írásmód, illetve az egybeírás vagy különírás kérdése is: megállapítható, hogy sok az ingadozás, így a tulajdonnévi vagy a köznévi státus eldöntése is sokszor nehéz. (Példák e két eset kereszteződésére, illetve „végpontjaira”: Fregoli szerep és fregoliszerep. ${ }^{37}$ ) Ehhez az alcsoporthoz elsősorban a nagybetüs személynevet tartalmazó szintagmák sorolhatók, melyek között vannak márkanevek, intézménynevek, egy verseny (játék?) és egy betegség neve is.

Márkanév részeként az olasz családnév a múlt század harmincas-negyvenes éveiben bukkant fel (1933, 1934: Fregolin fürdőkádpaszta és 1943: Fregoli befözöpor). ${ }^{38}$

Az ezt a nevet viselö intézmények sorába elsősorban (ma már nem müködő) budapesti kávéházak, bisztrók, boltok tartoztak, mind még a müvész aktív időszakában (pl. a Fregoli kávéház 1907-ben Pesten a Kis-stáció u. 5. sz. alatt volt, tulajdonosa: Neuvelt Gyula), mind az utóbbi évtizedekben (a Fregoli kávézó Budán a Karinthy Frigyes út 13. sz. alatt volt; a Fregoli Shop pedig lakberendezési üzlet volt a 2009-2013 közötti időszakban Budapest belvárosában, a Bástya u. 12. alatt). ${ }^{39}$ - A Fregoli színészegylet nevü társulatot három színész alapította meg 2005-ben; ${ }^{40}$ talán ugyanarról az intézményről van szó, amely 2015 augusztusában Nagyváradon lépett fel (az utóbbiról szóló hírekben ugyanis a Fregoli Színház elnevezés áll ${ }^{41}$ ). - Békés városában müködött a Fregoli társastáncklub, ennek neve ma már Fregolina társastánc klub. ${ }^{42}$

Néhány évvel Fregoli magyarországi fellépése után a budapesti Polo Club versenyszámai közé iktatta a Fregoli-verseny nevü játékot. A leírás szerint a verseny így zajlott: „A Fregoli versenyben nyolcz úr vett részt. A pályázók egy-egy bábut kaptak, a melyekkel a hölgyekhez kellett lovagolniok, a kik átöltöztették a babákat. Egy pózna megkerülése után a csapatnak ismét a juryhez kellett galoppoznia a ki elsőnek ért oda s rendben átadta a babát, kapta a tiszteletdíjat." ${ }^{23}$ Amint látjuk, inkább társasjátékról, mint valódi lovasversenyről van tehát itt szó, így nem is véletlen, hogy a „verseny” - nevével együtt - igen gyorsan a feledés homályába merült.

${ }^{37}$ Egy 2019. febr. 13-án lefuttatott Google-keresés eredménye ez lett: fregoliszerep 84 találat; Fregoli szerep, fregoli szerep és ,,fregoli” szerep (együtt) 7 találat.

${ }^{38}$ Adatok a Festék közlöny c. újság 1933. és 1934. évi számaiban; reklám a Pesti Hírlapban (1943. júl. 11: 8).

${ }^{39}$ Források: Budapesti Czím- és lakásjegyzék 1908: 852; internetes információs oldalak (https://www.nyitvatartas24.hu/uzlet/Budapest-FREGOLI\%2520K\%25C3\%2581V\%25C3\%258 9Z\%25C3\%2593\%2520Moka\%2520International\%2520Kft.-568165A.html; http://visitbudapest. travel/local-secrets/fregoli).

${ }^{40}$ Az alapítók: Hajdú Steve, Magyar Attila és Szakács Tibor. Az egyesület vándortársulatként müködik, programjukon elsősorban magyar népszínművek szerepelnek.

${ }^{41}$ Híradás az eseményről a nagyváradi Reggeli Újságban (amely 2018. febr. végéig jelent meg).

${ }^{42}$ Az erről szóló híreket 1. a Békési Újság 2009-2010-es számaiban.

${ }^{43}$ A játékról a Vadász- és Versenylap (1903. ápr.-máj.) és a Vasárnapi újság (1903. máj. 31: 356) számaiban találtunk híradást és leírást: ezekben a játék neve előfordul Fregoli verseny, Fregoliverseny, fregoli-verseny írásmódokban is. Az idézet szintén a Vadász- és versenylapból származik (1903. máj. 8: 242). 
E csoportban utolsóként megemlíthetjük még a több nyelvben is jelen lévő (ol. sindrome di Fregoli vagy fregolismo, ang. Fregoli delusion, ném. FregoliSyndrom) pszichés betegség nevét: Fregoli-szindróma, Fregoli-téveszme. ${ }^{44}$ Előbbi címmel alkotott színpadi múvet Réti Anna (a darab bemutatója Budapesten a Trafó Színházban 2009. szept. 8-án volt ${ }^{45}$ ).

4. Köznevesülés (deonímia). A köznevesülés eseteire rátérve megemlítjük, hogy Fregoli, fregoli címszó megjelent már a 20. sz. elején néhány szótárunkban, mégpedig KELEMEN idegen szavak szótárában 1917-ben (még nagy kezdőbetűvel és „ol. átváltozómủvész” ekvivalenssel), továbbá ECKHARDT 1935-ös magyar-francia szótárában a következő jelentésekben: „1. (konyh) séchoir $m$ (de plafond) mobile; 2. (átváltozó müvész) homme à transformations". Az előbbi két szakirodalmi forrásra hivatkozó EtSz.-ben szintén két aljelentésben szerepel: „1. 'bámulatos gyorsasággal külsejét változtató mủvész' [...] 2. 'konyhában, mosókonyhában kifüggeszthető ruhaszárító készülék'.” Az is megjegyzendő, hogy ebben a fontos alapmüben a szó (CAFFARELLI-MARCATO 2008 alapján: tévesen) összefüggésbe van hozva az „ol. fregola 'das Laichen der Fische, ívás" " szóval. ${ }^{46}$ Történeti és szinkrón szótárainkban a későbbi korokban is rendre szerepel. ${ }^{47}$ Ezek az adatok mutatják a szónak a magyarban meglévő vitalitását, ami valószínűleg a fregoli szóval jelölt háztartási kiegészítő eszköz népszerüségével és elterjedtségével áll kapcsolatban.

Mint Magyarországon ismeretes, egy a plafon alá felhúzható szárítóalkalmatosságról van szó, ami feltalálása (azaz a 20. sz. eleje) óta eleinte szinte nélkülözhetetlen, de máig használatos (mert igen praktikus) berendezési tárgya lett a (nagy)városi lakásoknak. ${ }^{48}$ Első megjelenésekor a fregoli fő alkotóelemei a fa-

${ }^{44} \mathrm{Az}$ angol Wikipédia leírása szerint: ,The Fregoli delusion is a rare disorder in which a person holds a delusional belief that different people are in fact a single person who changes appearance or is in disguise.” Első leírói 1927-ben P. Courbon és G. Fail voltak (https://en.wikipedia.org/wiki/ Fregoli delusion).

${ }^{45}$ Alcíme: ,avagy nem a ruha teszi az embert”. Kritikák a müről és az előadásokról számos helyen találhatók az interneten. Az előadást létrehozó stáb munkájában részt vett az olasz Claudio Stellato is.

${ }^{46}$ CAFFARELLI-MARCATO családnévszótárában (2008) a Fregoli családnév kapcsán többféle lehetséges eredet is szerepel (de az EtSz.-ben álló nincs közöttük): lehet ragadványnév az ol. frégola 'briciolo, minuzzolo' [m. 'morzsa'] jelentésü szóból; Calabriában a frégula 'ferula' [m. 'pálca, sín, pásztorbot'] szó állhat mögötte, illetve lehetséges még egy (a Federigo alakból származó) Frego névtő továbbképzése is.

${ }^{47}$ EtSz.; TESz.; EWUng.; ÉKsz.'; BAKOS 2005; TÓTFALUSI 2005, TOLCSVAI NAGY 2007; ESz.; ÉrtSz.+; FÁBIÁN-SZABÓ 2010; KISS 2012. Megemlítjük, hogy HERCZEG GYULA kétkötetes olasz-magyar nagyszótárában (HERCZEG 1978) még szerepel a (szính minősítésü), fregolismo gyors díszletcserélés" ekvivalencia, amely azonban már kimaradt a szótár későbbi, egykötetes változatából (HERCZEG-JUHÁSZ 2000). Az ellenkező irányú (tehát magyar-olasz) szótárak közül a szó szerepel KOLTAY-KASTNER 1981-ben két aljelentésben: 1. (átváltozó müvész) trasformista, 2. (száritó) tenditoio (sic!); ugyanennek a szótárnak az egykötetes, későbbi változatában (KOLTAY-KASTNER-JUHÁSZ 2000) már csak a második aljelentés áll, továbbra is tenditoio ekvivalenssel - holott ez jelentősen ritkább alak, 1. a világhálón - és megtoldva (az itt kevéssé értelmezhető) saliscendi szóval. A szó nem címszó FóRIS 2002-ben.

${ }^{48}$ Népszerüségének (és szükségessének) egyik oka az is lehetett, hogy a nagy bérházakban a megszaporodó lopások miatt a háziasszonyok, cselédek már nem a közös padlástérbe vitték szárítani 
keret és a kifeszített spárgák voltak, mai változatánál a keret fém, és a spárgát felváltotta a müanyag zsinór. Rendszeres helye korábban a konyha volt ${ }^{49}$ (ahol a konyhai tevékenységek során felmelegedett levegő meggyorsította a száradási folyamatot); mai helye inkább a fürdőszoba vagy valamilyen mellékhelyiség. (Az első fregolik tervképe látható a szabadalmi kérvényben.)

Bizonytalanság övezi ennek az elnevezésnek a történetét: azt, hogy hogyan lett éppen ennek az olasz átváltozómüvésznek a családneve e (tipikusan csak magyar) szárító alkalmatosság neve. Talán a Bálint Marcell színházi rendező és író önéletrajzi írásában találunk a megfejtéshez vezető adatokat, szavait azonban fenntartásokkal kell kezelnünk. Visszaemlékezéseiben (Bálint 1990: 16-17) az író azt állítja, hogy édesapja, Blau Jónás találta fel a felhúzható ruhaszárítót. ${ }^{50} \mathrm{~A}$ (világhálón is elérhető adatbázissal rendelkező) Szellemi Tulajdon Nemzeti Hivatalának dokumentumai között a kérelem - 1900. június 12-i dátummal - valóban regisztrálva van, de (a vágsellyei lakosként feltüntetett) Blau Jónás n é nevén, a dokumentumban szereplő tárgy neve pedig ruhaszáritó; 1901 márciusában azután Blau Jónásné Újítás ruhaszárítókon címủ kérelmet is beadott a hivatalba (tehát még ebben is a ruhaszáritó elnevezés szerepel). ${ }^{51}$ Bálint Marcell visszaemlékezéseiben ezzel szemben az áll, hogy a találmány és neve az 1896-os Millenniumi Ünnepségekhez köthető: ekkor ugyanis a Városligetben (az ekkor már négy gyermekes) Blau Jónás megnézte Marcello (sic!) Fregoli egyik fellépését, és ez inspirálta arra, hogy friss találmányát a Fregoli névre keresztelje, és ,,a Marcello nevet pedig számomra tartotta fenn" (Bálint 1990: 17). ${ }^{52}$ Összefoglalva a Bálint szövegében rejlö információkat: az író szerint tehát előbb történt meg a szárító feltalálása, ez körülbelül egybeesett Fregoli 1896-os budapesti fellépésével, s ennek hatására adta édesapja a fregoli nevet találmányának. Több ellentmondás is rejlik azonban ebben az elbeszélésben: számos forrásból rekonstruálhatóan ${ }^{53}$ Fregoli 1895-96-ban nem járt Budapesten (ekkoriban ugyanis elsősorban Észak- és Dél-Amerikában turnézott); mint már említettük, Budapesten 1900. december 1.

a ruhákat (1. ehhez József Attila Mama c. versének híressé vált sorait), hanem ki-ki a saját lakásában próbálta ezt a mindennapi élethez szorosan hozzátartozó feladatot megoldani. L. ehhez: „A ruhákat a gyakori lopások miatt (padlás) a konyhában fregolin szárogatták” (TAKÁCS 2014: 176).

${ }^{49}$ Erre utaló megjegyzést találunk több nyelvészeti forrásban is (ECKHARDT 1935; EtSz.; KARINTHY 1947: 25).

${ }^{50}$ Valószínűleg Bálint önéletrajza nyomán születhetett meg Szőke András (2000. febr. 3-i dátumú) blogírása (http://www.webdesign.hu/merliner/napi/szinema00.html).

${ }^{51}$ http://epub.hpo.hu/e-kutatas; keresőszó: „Blau Jónásné”.

${ }^{52}$ „Már ott a Városligetben elhatározta [...], hogy szabadalmaztatni fogja a ruhaszárítót és ennek FREGOLI nevet ad. Így is tett.” Saját nevéhez kapcsolódó megjegyzéséhez hozzá kell tennünk, hogy Bálint Marcell 1911-ben, tehát Leopoldo Fregoli - Bálint által feltételezett - látogatásához képes 15 , a találmány beadásához képest 10 évvel később született.

${ }^{53}$ A világhálón elérhető számos forrás közül itt most csak kettőre hivatkozunk, a Wikipédia olasz, illetve német nyelvü, Fregoliról szóló oldalaira: „Tra il giugno 1895 e il febbraio 1896 fece una tournée in America Latina esibendosi in Argentina, Brasile e Uruguay, poi nel maggio del 1896 debutta negli Stati Uniti dove rimarrà in tournée per 6 mesi” [,...1896 májusában az Egyesült Államokban debütált, ahol még 6 hónapon át turnézott”]; „1896 führte sein Weg durch Spanien, Süd- und Nordamerika”. 
és 1901. január 31. között lépett fel, ekkor azonban a szabadalmi kérvények (ruhaszáritó néven) már kb. fél éve be voltak adva a kompetens hivatalban.

Szintén Bálint elbeszélése szerint a ruhaszárító szabadalmát édesapja később eladta egy Breslauer nevü asztalosnak, ${ }^{54}$ aki belefogott a gyártásába, és sikeres termékké tette. Évekkel később (1922 szeptemberében) azután maga Breszlauer Izidor is bejegyzési kérelemmel fordult a szabadalmi hivatalhoz (tervezete a felhúzható ruhaszárító méretének az aktuális elhelyezési körülmények szerinti megváltoztathatóságára irányult): a fregoli elnevezés azonban ebben a dokumentumban sem szerepel. ${ }^{55}$

Tovább bonyolítja a helyzetet, hogy elterjedésével párhuzamosan a ruhaszárítót több néven is említették. A 20. sz. elejétől kezdve a korabeli napilapokban több hirdetést is találtunk (pl. magától Blau Jónástól ${ }^{56}$ de egy bizonyos Spiegel Józseftől is ${ }^{57}$ ), amelyekben a Fregolin ruhaszárító elnevezés szerepel. Breszlauer később (1929-ben ${ }^{58}$ ) kísérletet tett a fregolia név elterjesztésére is (mely még 1933-ban is felbukkant $t^{59}$ ); mint láttuk, ez a névváltozat már korábban előfordult női tulajdonnévként, tehát lehetett „hívószó” funkciója is.

Az EtSz. vonatkozó szócikkének záró mondata még ez volt: „A fregoli 'ruhaszárító' jelentése magyarázatra szorul". A fellelt adatok és források valószínűleg sokat segítenek KARINTHY FERENC (olasz-magyar szakos) nyelvész és szépíró, illetve a TESz. és az EWUng. (egymással nem teljesen megegyező) magyarázatainak összesimításában azt illetően, miért és hogyan válhatott a Fregoli tulajdonnév a magyarban 'ruhaszárító' jelentésü köznévvé. Olasz jövevényszavaink címü doktori értekezésében KARINTHY a fregoli szócikkben kognitív-metaforikus folyamatot tételez fel, melyben párhuzam van Fregoli ruhaváltoztatásai és a szárítón a ruhák szintén folyamatos változása között: „A [fregoli] szó 'ruhaszárító berendezés' jelentése annak felismeréséből keletkezhetett, hogy a ruhaszárító készülék, hasonlóan az átváltozó müvészhez, sokféle, sokszínü, állandóan változó ruhanemüt hord." (KARINTHY 1947: 25). E magyarázat szerint tehát köznevesülési folyamatról van szó (a mủvész tulajdonnevéből származik a 'ruhaszárító' jelentésü köznév). A TESz. is említi a személynévből kiinduló metaforikus hátteret, ugyanakkor mégis inkább márkanévből származónak látja a fregoli 'ruhaszárító’ köz-

${ }^{54}$ Bálint így ír: „Édesapám nagyon kiskeresetü, pénztelen volt, ezért a Fregolit nem tudta legyártani. Így kevés pénzért eladta a készítési jogot, a név használatát egy Hunyadi téri Breslauer nevű asztalosnak. Ö ezen meggazdagodott. Így ebböl családunknak csak 1-1 Fregoli-ruhaszárító, nekem pedig az utónevem jutott." (Bálint 1990: 17.) - Bálint könyvéből (1990: 16) és a világhálón is elérhető adatokból kiderül, hogy Blau Jónás a trieszti illetőségủ Generali Biztosító ügynöke lett, 1930 októberében halt meg (1. pl. Pesti Hírlap 1930. okt. 23.).

${ }^{55}$ Rajzzal is illusztrált adatlap (http://epub.hpo.hu/e-kutatas). A dokumentum címe: Ruhaszárító készülék.

${ }^{56}$ Rajzzal kísérve: Budapesti Hírlap 1901. jan. 29: 15.

${ }^{57}$ Spiegel József és fia, Budapest, Sajó u. 5/a. Az adatok forrása: budapesti telefonkönyvek az 1912-1943 évekből; 1929-től a lakcím: Egressy út 46.

${ }^{58}$ A budapesti távbeszélő-hálózat előfizetőinek névsora, 1929 májusa: „Breszlauer Izidor asztalos m., előszoba, konyha és mosókonyha berendezések raktára, Fregolia ruhaszárító készítő, VI. Hunyadi-tér 7. Tel. 960-80".

${ }^{59}$ „Eladó [...] fregolia ruhaszáritó” (Esztergom és vidéke 1934. okt. 25: 4). 
nevet. ${ }^{60} \mathrm{~A}$ TESz. szerzőinek felfogása szerint tehát első fázisban transzonímiáról (személynévből márkanév), második fázisban pedig köznevesülésről (márkanévböl köznév) lehet szó. Az EWUng.-ban azután egy újabb - de véleményünk szerint a legkevésbé valószínü - magyarázat bukkan fel, és (megmagyarítva) ugyanez szerepel egyelöre a most készülö ÚESz.-ben is.$^{61}$ - Felvetünk egy újabb motivációs lehetőséget is: ${ }^{62}$ mivel Fregoli színpadon lépett fel, talán lehetséges, hogy a függöny mögötti segítói az egyes megjelenések után levett ruhákat egy zsinórpadlás segítségével húzták fel a magasba, hogy minél gyorsabb lehessen a szerepek váltakozása. Akár a zsinórpadlás is lehetett tehát a ruhaszárító fregoli „előképe”. - Az adatok tükrében az említett folyamatok és mozzanatok egymást erősítve müködhettek és alakíthatták a jelentéseket.

4.1. Köznevesülés képzőkkel. A Fregoli családnévből a magyarban képzőkkel megalkotott, köznevesült alakok több más európai nyelvben is jelen vannak; a magyar változatok gyakran szerepelnek szótárainkban.

A 20. sz. első évtizedeiben született meg a fregoliada/fregoliáda szó, amely két korabeli idegen szavak szótárában (KELEMEN 1917; SzÉCSI 1936) is címszó, mindkettőben gyors átalakulás ekvivalenssel (a szó motivációja teljesen világos, hiszen Fregoli villámgyorsan öltözött át színpadi jeleneteiben). ${ }^{63}$ A szó egy (Fregoli által inspirált) irodalmi-színházi múfaj nevévé is vált (szinonimaként erre talán az ang. sketch szót lehet használni): alig néhány hónappal követi csak Fregoli budapesti fellépéseit a magyar sajtóban fregoliada írásváltozatban feltünt alak. ${ }^{64}$ További, immár -á-s írásmódú változata (fregoliáda) felbukkan például Ady Endre munkásságában (1905-ben $\left.{ }^{65}\right)$, továbbá: a Nemess Ernö ${ }^{66}$ által írt A betörő című darab kapcsán és egyéb kabaréprogramok említésekor (Színész-felvétel, 1910 és Fekete párduc, 1921: ezekhez l. AlPÁR 1978: 36, 327). Ma e szónak régies-irodalmi íze van.

Az ol. fregolismo szó a magyarban fregolizmus alakban jelent meg és (más nyelvekhez hasonlóan) a harmincas évektől kezdve használták '(át)változás, vélemény- és pártváltoztatás (elsősorban a politikában)' jelentésben, melynek azonban korabeli szótárainkban nem leltük nyomát. HERCZEG 1978-ban publikált kétkötetes nagyszótárában szerepel (a színházi használatúnak besorolt) fregolismo, gyors díszletcserélés magyar ekvivalenssel.

${ }^{60}$ „A 2. és a 3. jelentés az 1.-ből jött létre hasonlóságon alapuló névátvitellel”; „2. jelentésében eredetileg márkanév lehetett”.

${ }^{61}$ „Bed 2 lässt sich mit der raschen Verstellbarkeit des Geräts erklären” (EWUng.); „A 2. jelentés a szerkezet gyors állíthatóságával magyarázható” (TESz.).

${ }^{62}$ Az ötletért PÁL FERENC (ELTE BTK Portugál Tanszék) kedves kollégámnak mondok köszönetet.

${ }^{63}$ Ebben a jelentésben használatos a szó például az Esztergom c. újságban (1908. szept. 27: 3).

${ }^{64}$ Szerepel a szó például a Fedák Sári berlini fellépéséről szóló híradásban (Szatmár c. újság, 1902. aug. 19.).

${ }^{65}$ A Budapesti Napló 1905. máj. 12-i számában, a budapesti Vígszínház repertoárjára került Miss Chipp c. darab bemutatójáról szóló Ady-írásban: „Van az ilyen darabban minden. Apacstragédia, hipnózis, kormányozható léghajó, Marconigraf, telepátia, anglománia és anglofóbia [...], szentimentálizmus, rémség, tánc, fregoliáda, zene".

${ }^{66}$ Író, újságíró (szül. 1889-ben). 
4.2. Köznevesülés jelzőként. Elemzésünk utolsó pontjaként felsorolunk még olyan eseteket, amelyekben a Fregoli név elveszítette tulajdonnévi státusát és - átvitel, illetve metaforizáció révén - szókapcsolatokban (vagy önállóan is) változást vagy változékony, bizonytalan jelleget fejez ki (valaki/valami hasonlít Fregolira; valaki/valami olyasmit csinál, úgy változik, mint Fregoli stb.).

Az egyik legkorábban felbukkanó eset az volt, amikor a fregoli szó jelzőként olyan ruhadarabokat jelölö szavak elé került, amelyeket mindkét oldalukra fordítva lehetett viselni (ang. double face), pl. fregoli kabát, fregoli babaruhák, fregoli modell. A szónak ez a jelentése több magyar szótárunkban szerepel, ${ }^{67}$ és a magyarázatokban mindig van utalás Leopoldo Fregoli személyére és müvészetének mibenlétére. A mostani vizsgálat során a 20. sz. eleje magyar sajtójában feltárt sok adat tükrében szükségesnek tünik e jelentés első előfordulásának szótárainkban közölt adatait antedatálni. Így például az EWUng.-ban szereplő 1958-as év bizonyosan javításra szorul, hiszen már 1901-ből (azaz Fregoli pesti fellépésének évéből!) találtunk e használatra példát újsághirdetésekben: ,(Fregoli) női kabátok”; 1911-es a Fregoli hordható felöltók adat, továbbá 1927-böl valók a fregoli modell és a fregoli ruhák használatok. ${ }^{68}$

A 'változás' jelentéskomponens teszi lehetővé a névnek, illetve szónak az olyan szóösszetételekben való használatát, mint pl. fregoli tervek: ezzel azt a tervezési-építési módot jelölték, amikor az egyhangúnak bizonyuló blokkházakat már szándékosan úgy tervezték meg, hogy némiképp variálhatók is legyenek. ${ }^{69}-\mathrm{Ma}$ is (bár ritkábban) használatos a politikai nyelvben a fregoli politikus 'köpönyegforgató', illetve a színházi nyelvben a fregoli szerep és a fregoli darab kifejezés.

A fregoli szavak elnevezés azokra a lexémákra vonatkozott, amelyeket elölről vagy hátulról olvasva ugyanazt a szót olvashatjuk ki (ezekre azonban inkább a palindrom szó használatos). ${ }^{70}$ A szintagma felbukkan a Világirodalmi lexikon 1975-ben megjelent kötetében (VilIrLex. 3.) is, de napjainkra már archaizmus lett: a hazánkban kiadott, ma leggyakrabban használt négy idegen szavak szótára közül csak az egyikben (TOLCSVAI NAGY 2007 fregoliszó) szerepel, innen azonban közvetlen utalással a palindrom szóra. - Ide kapcsolható (az igen ritka) fregoli-vers [sic!] kifejezés is: ebben a verssorokat tetszőlegesen fel lehet cserélni, de mindig lesz értelmes tartalom. ${ }^{71}$

Úgy tủnik, hogy a fregoli szónak a harmincas években argónyelvi, immár elfelejtett jelentése is volt: szerepel ugyanis A magyar fattyúnyelv szótára címü munkában (ZOLNAY-GEDÉNYI 1945-1967), 'egyfajta kártya' jelentésben.

${ }^{67}$ TESz.; EWUng.; ÉKsz.2; ESz.; ÉrtSz.+; BAKOS 2005; Tótfalusi 2005; TolcsvaI NAGY 2007.

${ }^{68}$ Forrásuk az említések sorrendjében: Budapesti Hírlap1901. márc. 10. (a kereskedő neve Kenyeres, üzlete: Budapest, Deák F. utca 13.); Pesti Hírlap 1911. szept. 24.; Budapesti Hírlap 1927. januári és februári számai.

${ }^{69}$ Délmagyarország 1983. júl. 19: 4.

${ }^{70}$ A szót ebben a jelentésben egy a húszas években elterjedt divatos játék neveként használták a budapesti irodalmi kávéházakban, és ebben a jelentésben utoljára talán Vargha Balázs használta Játékkoktél című könyvében (Minerva Kiadó, Budapest, 1967).

${ }^{71}$ Egy újságcikkhez írott olvasói hozzászólásból (https://www.delmagyar.hu/szeged_hirek/a koztarsasagi_elnok_valasztasarol/2274310). 
Neologizmusoknak lehet tekinteni viszont a következő szintagmákban való használatokat: fregoli étterem (ami nappal önkiszolgáló, este viszont pincérek szolgálnak fel benne); $;^{72}$ fregoli orvos/dolgozó/zenész/pincér stb. 'olyan orvos/ munkás/zenész/pincér stb., aki helyettesíti egyik kollégáját, csak beugrik helyette'; ebben a jelentésben önállóan, állítmány névszói részeként is lehet használni. ${ }^{73}$ Ez a jelentés és használat két szótárunkban is említve van (TOLCSVAI NAGY 2007-ben a 4., az ÉrtSz.+-ban pedig a 3. aljelentés). ${ }^{74}$

Ebbe a csoportba tartozik, de hapaxnak tekinthető a - hasonlóságon alapuló fregoli repülési pálya kifejezés. ${ }^{75}$

5. Az olasz Fregoli családnév magyar megjelenéseinek áttekintését azzal zárhatjuk, ${ }^{76}$ hogy nem sok más esetet lehetne említeni, amelynél egy idegen családnév transznominális és denominális változatai és használatai ilyen gazdagon burjánoznának. Leopoldo Fregoli sajátos müvészete tehát máig tovább élő nyomokat hagyott a magyar gondolkodásban, s így a magyar nyelvben is.

Kulcsszók: clothes airer, deonymisation, Leopoldo Fregoli, transonymisation.

\section{Hivatkozott irodalom}

Alpár Ágnes 1978. A cabaret. A fơvárosi kabarék müsora. Magyar Színházi Intézet, Budapest.

AlPÁr ÁGNES 1991. A Városligeti Színkör. Országos Színháztörténeti Múzeum és Intézet, Budapest.

BAKOS FERENC 2005. Idegen szavak és kifejezések szótára. Akadémiai Kiadó, Budapest. BÁLINT MARCELl 1990. Elmondom, mert igy történt ... Tevan Kiadó, Budapest.

BENEDEK, NÁNDOR 1978. Parole d'origine italiana nel lessico dell'ungherese contemporaneo. Giano Pannonio. Annali italo-ungheresi di cultura. [Liviana Editrice, Padova.] 1: 143-153.

${ }^{72}$ Magyar Ifjúság 1982/7: 7.

${ }^{73}$ „Aztán gebineseknél dolgoztam, meg fregoli voltam presszókban” (Szakonyi Károly: A füst http://dia.pool.pim.hu/html/muvek/SZAKONYI/szakonyi00248/szakonyi00301/szakonyi00301. html); „De már csak a jövő héten dolgozok ennek a bírónőnek, utána ún. ,fregoli” leszek, ez nálunk azt jelenti, hogy nincs bírója, és annak segít, akinek sok melója van” (bejegyzés egy internetes fórumon - (https://www.babanet.hu/tarsalgo/viewtopic.php?f=405590\&t=435432\&start=2350).

${ }^{74}$ TOLCSVAI NAGY szótárában: „,másokat helyettesítő, mindenféle alkalmi munkát végző személy”. Az ÉrtSz.+ példája: „Fél évig ő volt a fregoli az irodában.”

${ }^{75}$ A kifejezést (zárójelben és idézőjelek közé téve) Szabó Zoltán Attila Pilótanélküli repülőgépeken alkalmazható szondázási módszerek vizsgálata és fejlesztése c. MSc diplomamunkájában (ELTE TTK Meteorológia szak, 2014.http://nimbus.elte.hu/tanszek/docs/MSc/2014/SzaboZoltanAttila_2014. pdf) találtuk. Megkeresésünkre (2018. 05. 28-31.) azt a választ kaptuk a szerzőtől, hogy a kifejezésben azért szerepel a fregoli jelző, mert a kutatócsoport tagjait a repülőgép oda-vissza mozgású pályája egy terület felett a fregoli jellegzetes kötélzetének mintázatára emlékeztette.

${ }^{76}$ Megjegyezzük, hogy érdemes lenne kutatni még a PIERRE-ÉMILE GounELLE (1850-1914) francia entomológustól származó Fregolia Listropteroides (1911) állatrendszertani (génusz)név megszületésének motivációját is. (KORSÓs ZOLTÁNnak, a Természettudományi Múzeum föigazgatójának itt köszönöm meg az erre vonatkozó kutatásokban nyújtott eddigi szíves segítségét.) 
BÖLCSKEI ANDREA - FARKAS TAMÁS - SLÍZ MARIANN 2017. Magyar és nemzetközi névtani terminológia. Hungarian and international onomastic terminology. International Council of Onomastic Sciences - Magyar Nyelvtudományi Társaság, UppsalaBudapest. https://doi.org/10.26546/5061110

CAfFarelli, Enzo 2013. Dimmi come ti chiami e ti dirò perché: Storie di nomi e di cognomi. Laterza, Roma-Bari.

CAffarelli, Enzo 2017. Deonimici e transonimi dal cinema. In: PATOTA, GiUseppe Rossi, FABIO ed., L'italiano al cinema, l'italiano nel cinema. Accademia della Crusca - goWare, Firenze.

Caffarelli, Enzo - Marcato, Carla 2008. Cognomi d'Italia. Dizionario storico ed etimologico. UTET, Torino.

ECKHARDT SÁNDOR 1935. Magyar-francia szótár. Eggenberger, Budapest.

ÉKsz. ${ }^{2}=$ Magyar értelmező kéziszótár. Főszerk. PuszTAI FERENC. Akadémiai Kiadó, Budapest, 2003.

ÉrtSz.+ = Értelmező szótár $+1-2$. Főszerk. EŐRY VILMA. Tinta Könyvkiadó, Budapest, 2007.

ESz. = Etimológiai szótár. Főszerk. ZAICZ GÁBOR. Tinta Könyvkiadó, Budapest, 2006.

EtSz. = GOMBOCZ ZOLTÁN - MELICH JÁnOS, Magyar etymologiai szótár. Magyar Tudományos Akadémia, Budapest, 1914-1944.

EWUng. = Etymologisches Wörterbuch des Ungarischen 1-3. Hrsg. LORÁND BENKÖ. Akadémiai Kiadó, Budapest, 1993-1997.

FÁBIÁN, ZSUZSANNA 2001. Prestiti-deonomastici tra italiano e ungherese. Tipi e casi [fregoli, viganó, milánói, bolognai]. In: SALVI, GIAMPAOLO - TAKÁCS, JÓZSEF szerk., A piè del vero. Studi in onore di Géza Sallay. Íbisz Könyvkiadó, Budapest. 51-69.

FÁBIÁN, ZSUZSANNA 2015. Nomi di famiglia di origine italiana in Ungheria e nell'ungherese. In: CAFfarelli, EnZO ed., Nomi italiani nel mondo. Serie QuadRION 5. Società Editrice Romana - ItaliAteneo, Roma. 103-124.

FÁBIÁN, ZSUZSANNA 2019. Le trasformazioni ungheresi di Fregoli. Rivista Italiana di Onomastica 25: 705-722.

FÁBIÁn, ZSUZSANNA - SZABÓ, GYÖZÖ 2010. Dall'Italia all'Ungheria. Parole di origine italiana nella lingua ungherese. FORUM Editrice, Udine.

FÓRIS ÁGOTA 2002. Magyar-olasz müszaki-tudományos szótár. Vocabolario tecnicoscientifico ungherese-italiano. Dialóg Campus Kiadó, Budapest-Pécs.

HERCZEG GyUlA 1978. Olasz-magyar szótár. Vocabolario italiano-ungherese 1-2. Akadémiai Kiadó, Budapest.

Herczeg GyUla - JuHÁsz ZsuZSANNA 2000. Olasz-magyar szótár. Vocabolario italiano-ungherese 1-2. Akadémiai Kiadó, Budapest.

KARINTHY FERENC 1947. Olasz jövevényszavaink. A Magyar Nyelvtudományi Társaság Kiadványai 73. Magyar Nyelvtudományi Társaság, Budapest.

KELEMEN BÉLA 1917. Idegen szavak és nevek szótára. Athenaeum, Budapest.

KISS GÁBOR 2012. Régi szavak szótára. Tinta Könyvkiadó, Budapest.

KOLTAY-KASTNER JEN 1981. Magyar-olasz szótár. Vocabolario ungherese-italiano 1-2. Akadémiai Kiadó, Budapest.

KoltAY-KASTNER Jen - JuHÁSZ ZSUZSAnNA 2000. Magyar-olasz szótár. Vocabolario ungherese-italiano. Akadémiai Kiadó, Budapest. 
LAKATOS ÉVA 1979. A lapkiadás mint üzlet. Magyar Könyvszemle 95: 140-163.

NAGY ENIKÖ é. n. „Biztos-e Ön abban, nincsen benn a Napban?” A „Nap” című szenzációlap bemutatása. Filologia.hu. http://www.filologia.hu/tanulmanyok/biztos-e-on-abbannincs-e-benn-a-napban-a-nap-cimu-szenzaciolap-bemutatasa.html (2019. 05. 31.)

SEREG MARIANN 2012. Az Így írtok ti szövegeinek textológiai vizsgálata. Irodalomtörténeti Közlemények 116: 554-569.

SZÉCSI FERENC 1936. Idegen szavak nagyszótára. Universum Könyvkiadó, Budapest.

TOLCSVAI NAGY GÁBOR 2007. Idegen szavak szótára. Osiris Kiadó, Budapest.

TAKÁCS ANETT 2014. Higiéniai és tisztálkodási szokások változása 1850-1920 között, különös tekintettel Budapestre. PhD értekezés. ELTE BTK, Budapest. http://doktori. btk.elte.hu/hist/takacsanett/diss.pdf (2019. 05. 31.)

TESz. = A magyar nyelv történeti-etimológiai szótára 1-3. Főszerk. BENKŐ LORÁND. Akadémiai Kiadó, Budapest, 1967-1976.

TÓTFALUSI ISTVÁN 2005. Idegenszó-tár. Idegen szavak értelmező és etimológiai szótára. Tinta Könyvkiadó, Budapest.

ÚESz. = Új magyar etimológiai szótár. http://uesz.nytud.hu (2019. 05. 31.)

VilIrLex. = Világirodalmi lexikon 1-18. Főszerk. KIRÁLY IsTVÁN. Akadémiai Kiadó, Budapest, 1970-1995.

ZoLNAY VILMOS - GEDÉNYI MiHÁLY 1945-1967. A magyar fattyúnyelv szótára. Kézirat. Országos Széchényi Könyvtár, Budapest.

\section{Hungarian metamorphoses of the name Fregoli}

The study aims to analyse the processes of transonymisation and deonymisation of the proper name Fregoli in Hungarian. Leopoldo Fregoli (1867-1936) was a quick change artist in the first half of the 20th century and (after a brief artistic tour in Budapest) became famous in Hungary, too: his great popularity resulted in various uses of his family name. The most used meaning of the word fregoli in Hungarian is 'clothes airer': the explicitations of this and other antiquated and new meanings are treated in this paper.

Keywords: clothes airer, deonymisation, Leopoldo Fregoli, transonymisation.

FÁBIÁN ZSUZSANNA

ELTE Eötvös Loránd Tudományegyetem 